\title{
Pengaruh Mendengarkan Musik Bagi Kenyamanan Pengendara Mobil Angkutan Umum Di Gresik
}

\author{
Muhammad Burhanudin Ganda Saputra \\ Program Studi Seni Musik Fakultas Bahasa dan Seni Universitas Negeri Surabaya \\ E-Mail: nda.ganda@yahoo.co.id
}

\begin{abstract}
Work comfortness is an important aspect for public transport drivers. They are prone to experience stress as a result of congestion, irregular eating patterns and deposit targets. One method that used to avoid stress is listening to music. Music provides a certain stimulus by offering other forms of emotion which are able to relieve stress. This research use quantitative explanative approach. This sampling method is purposive sampling. Object of this research is the public transport bus driver in Gresik City Bunder Terminal. The data found was processed using quantitative data analysis techniques. Based on data findings in the field, all 10 respondents listened to music. $90 \%$ of them like the dangdut music genre. $10 \%$ who listen to music in addition to the average dangdut respondents listen to music because it can relieve stress. By using a rating scale, it was found that listening to music had an effect on the comfort of public transport drivers in Gresik City. That is equal to $71.2 \%$ and is classified as strong influence. So it can be concluded that listening to music for public transport drivers in the City of Gresik affects their comfort. Especially while driving because it can relieve stress and increase focus.
\end{abstract}

Keywords : comfort, listening to music, public transportation in Gresik.

Abstrak: Kenyamanan bekerja menjadi aspek penting bagi pengemudi angkutan umum. Mereka rentan mengalami stress sebagai dampak dari kemacetan, pola makan tidak teratur dan target setoran. Salah satu cara yang digunakan untuk menghindari stress yaitu mendengarkan musik. Musik memberikan stimulus tertentu dengan menawarkan bentuk emosi lain dimana mampu meredakan stress. Penelitian ini menggunakan pendekatan kuantitatif eksplanatif. Metode pengambilan sampel adalah purposive sampling. Objek penelitian ini yaitu pengemudi bus angkutan umum di Terminal Bunder Kota Gresik. Data yang ditemukan diolah dengan menggunakan teknik analisis data kuantitatif. Berdasarkan pada temuan data dilapangan, dari 10 responden seluruhnya mendengarkan musik. 90\% diantaranya menyukai genre musik dangdut. 10\% yang mendengarkan musik selain dangdut rata-rata responden mendengarkan musik karena dapat meredakan stress. Dengan menggunakan rating scale, ditemukan bahwa mendengarkan musik berpengaruh pada kenyamanan pengemudi angkutan umum di Kota Gresik. Rating scale menunjukkan angka 71,2\% dan tergolong kuat pengaruhnya. Maka, dapat disimpulkan bahwa mendengarkan musik bagi pengendara angkutan umum di Kota Gresik berpengaruh pada kenyamanan mereka. Terutama saat mengemudi karena dapat meredakan stress dan meningkatkan fokus.

Kata kunci : kenyamanan, mendengarkan musik, angkutan umum kota Gresik.

\section{PENDAHULUAN}

Kehadiran angkutan umum dalam sebuah wilayah merupakan salah satu alternatif yang baik untuk mengurangi kemacetan. Namun, pengguna angkutan umum saat ini semakin berkurang. Hal ini terkait dengan perubahan tren dan mudahnya mendapatkan kendaraan pribadi, dengan bantuan kredit misalnya. Para pengemudi maupun pemilik usaha angkutan umum nampak cukup kerepotan dengan hal ini. Pasalnya dengan terus berkurangnya penumpang, maka berkurang penghasilan bagi pemilik usaha. Bagi pengemudi, terutama pengemudi yang bukan pemilik kendaraan justru masalah ini lebih pelik lagi. Mereka harus menepati jumlah target setor perhari untuk diserahkan kepada pemilik angkutan. 
Berubahnya tren dari menggunakan kendaraan umum ke kendaraan pribadi merupakan masalah baru bagi lingkungan perkotaan. Ketika mayoritas lebih memilih kendaraan pribadi, tingkat kemacetan meningkat. Pemerintah Gresik menanggapi persoalan ini dengan serius. Dishub Gresik meluncurkan aplikasi E-Angkot pada tahun 2017 lalu. Aplikasi ini berfungsi untuk memesan angkutan umum secara online melalui android. Cara kerjanya kurang lebih mirip dengan aplikasi ojek online. Pemerintah Gresik berharap dengan kemudahan memesan angkutan umum, minat masyarakat untuk menggunakan angkutan umum semakin meningkat.

Upaya Pemerintah Kota Gresik patut diapresiasi dalam memperhatikan kepentingan pengemudi angkutan umum dan sekaligus upaya mengurangi kemacetan. Ketika menyoal pengemudi angkutan umum Pemerintah Gresik juga perlu memperhatikan aspek penting yang berkaitan dengan pengemudi, yakni kenyamanan kerja. Hal yang tampak sepele ini dapat meningkatkan produktivitas dan tingkat keselamatan berkendara. Pengemudi angkutan umum rentan terserang penyakit tidak menular tiba-tiba, seperti tekanan darah tinggi dan asam urat (Suara.com, 2016). Selain itu, pengemudi angkutan umum juga mudah terserang stres akibat kemacetan, pola makan tidak teratur, dan target pendapatan perhari (setoran) (Sindonews, 2018). Hal-hal ini yang kemudian dapat menjadi penyebab stres bagi pengemudi angkutan umum.

Stres disebabkan oleh adanya peristiwaperistiwa atau penyebab lain yang disebut dengan stressor. Dapat dikatakan bahwa stres merupakan respon tubuh terhadap stressor. Tubuh mulai bertindak melindungi diri begitu mengenali kehadiran stressor. Tindakan yang muncul ada dua mekanisme, yaitu menghadapi atau melarikan diri dari stressor. Secara umum, mekanisme pertahanan diri ketika menghadapi stres adalah tubuh akan secara otomatis (Halim, 179): 1) melepas bahan bakar (gula dan lemak) untuk menyediakan energi instan; 2) napas semakin cepat agar mampu mengambil oksigen ekstra untuk membakar gula dan lemak; 3) tekanan darah dan detak jantung meningkat untuk menjamin aliran darah ke otot; 4) otot menegang siap melakukan tindakan pertahanan diri; 5) indra menjadi lebih peka (pendengaran lebih sensitif, pupil membesar, penciuman menjadi tajam) sehingga menjadi lebih awas dengan lingkungan sekitar.
Seperti manusia lain pada umumnya, pengemudi angkutan umum juga memiliki caranya sendiri dalam menghadapi stres, yakni mendengarkan musik. Musik merupakan sebuah karya seni bunyi (suara) yang diciptakan oleh manusia. Musik hadir sebagai pengaktualisasian pikiran dan perasaan penciptanya melalui komposisi atau karya musik yang dihasilkan. Musik merupakan seni pengungkapan gagasan melalui bunyi, yang unsur dasarnya berupa melodi, irama, dan harmoni. Unsur pendukung musik berupa bentuk gagasan, sifat, dan warna bunyi. Dalam penyajiannya, sering masih berpadu dengan unsur-unsur yang lain, seperti bahasa, gerak, ataupun warna (Syafiq, 2003). Menurut Jamalus (1988 dalam Apriadi, 2012) pada dasarnya unsur-unsur musik dapat dikelompokkan unsur-unsur pokok yaitu harmoni, irama, melodi, atau struktur lagu danunsur-unsur ekspresi yaitu tempo, dinamika dan warna nada. Kedua unsur musik tersebut merupakan suatu kesatuan yang tidak dapat dipisahkan.

Musik menjadi bagian hidup yang tak terpisahkan dari kegiatan sehari-hari. Terkait stres, sebuah penelitian yang ditulis Daniel Levitin menunjukkan musik menawarkan pengalih perhatian yang dapat membantu depresi. Musik memberikan stimulus tertentu dengan menawarkan bentuk emosi lain dalam komposisinya yang membantu meredakan stres. Musik juga sering dikaitkan dengan stimulus kinerja otak. Beberapa penelitian mengkaji mengenai pengaruh musik terhadap kinerja otak, seperti memperdengarkan musik klasik pada janin mampu membuat anak lahir cerdas dan emosi yang stabil (Kompasiana, 2011).

Perkembangan penelitian tentang musik kini bukan hanya terbatas sebagai bagian dari seni, namun juga sebagai objek penelitian sosiologi, psikologi, bahkan ekonomi. Musik tidak hanya dinikmati sebagai sebuah mahakarya, namun juga mengandung makna simbolis, nilai jual, sampai dengan alat perjuangan. Musik sebagai karya seni tidak membatasi dirinya untuk dianalisis dengan disiplin ilmu lain yang berkaitan. Salah satunya adalah dengan psikoanalisis. Musik dapat digunakan untuk menentukan klas seseorang melalui genre yang didengarkannya, misal genre dangdut sebagai musik populer untuk kaum pinggiran (rakyat jelata), sedangkan genre jazz untuk kaum priyayi dan lingkungan kerajaan. Lebih jauh lagi, musik juga dianalisis sebagai 
salah satu aspek yang tidak luput dari jerat modernisasi sekaligus komodifikasi. Komodifikasi ini dilakukan oleh industri hiburan. Musik menjadi lebih "teratur" dalam artian memenuhi selera pasar. Misalnya penentuan durasi, penggolongan genre, menyeuaikan minat pasar yang semuanya menjadikan musik sebagai barang komoditas.

Namun hal ini masih menjadi suatu pro kontra karena terkait adanya pernyataan dalam Undang-Undang Nomor 22 Tahun 2009 Pasal 106 ayat 1 menyebutkan bahwa "Setiap orang yang mengemudikan kendaraan bermotor di jalan wajib mengemudikan kendaraannya dengan wajar dan penuh konsentrasi." Penjelasan Pasal 106 ayat 1, "penuh konsentrasi" adalah tidak terganggu perhatiannya karena sakit, lelah, mengantuk, menggunakan telepon atau menonton televisi dan video yang terpasang di kendaraan. Hal yang juga termasuk mengganggu adalah minum minuman beralkohol atau obat-obatan yang mempengaruhi kemampuan mengemudi. Sehingga terjadinya pertanyaan yang muncul dalam masyarakat apabila salah dalam menanggapi pernyataan tersebut, apakah musik diperbolehkan untuk didengarkan pada saat berkendara atau tidak.

Musik juga dapat mempengaruhi emosi seseorang yang sedang mengemudikan kendaraan terutama mobil. Sebagai contoh musik bergenre rock, metal, hardcore, dan semua musik yang mempunyai dentuman yang keras dan tempo yang cepat akan cenderung membuat pengendara tersebut memacu kendaraannya lebih cepat dari normal. Sebaliknya, jika mendengarkan musik yang bergenre jazz, pop, klasik, dan musik yang mempunyai dentuman mendayu-dayu dan dengan tempo yang cenderung pelan, akan membuat pengemudi tersebut memacu kendaraannya lebih pelan dari normal. Penelitian ini dilatarbelakangi oleh fenomena mendengarkan musik sebagai sarana untuk membangun konsentrasi atau penghilang konsentrasi pada pengendara mobil angkutan umum yang memiliki rutinitas dalam kegiatannya sehari-hari. Untuk itu sangat pentingnya dilakukan sebuah penelitian untuk mengungkap problematika apa saja yang dihadapi oleh pengendara mobil angkutan umum di Gresik. Sebab, kenyamanan pengemudi pada lingkungkan ketika mengemudi sangat berpengaruh terhadap keselamatannya selama berkendara.

Masalah-masalah yang dapat diidentifikasi dari gambaran di atas adalah perlunya mendeskripsikan pengaruh antara mendengarkan musik terhadap kenyamanan pengendara mobil angkutan umum di Gresik. Adapun hipotesis dalam penelitian ini terdiri dari ho (mendengarkan musik tidak berpengaruh terhadap kenyamanan pengemudi angkutan umum); dan, ha (mendengarkan musik berpengaruh terhadap kenyamanan pengemudi angkutan umum).

\section{METODE}

Penelitian ini menggunakan pendekatan kuantitatif yang bersifat eksplanatif. Jenis maupun sifat penelitian ini merujuk pada buku "Metode Penelitian Kuantitatif dan Kuantitatif" yang ditulis oleh Jonathan Sarwono. Berdasarkan sisi tingkat pemahaman, penelitian ini tergolong ke dalam desain penelitian ex post facto. Desain ini "...menghasilkan tingkat pemahaman persoalan yang dikaji pada tataran permukaan..." (Sarwono, 2006: 82).

Penelitian ini dilakukan dengan jangka waktu dua bulan. Sampel ini ditentukan dengan teknik purposive sampling atau sampling bertujuan. Teknik ini termasuk desain penentuan sampling non-probabilitas dengan cara kesesuaian (convenience). Hal ini dilakukan dengan, memilih unit-unit analisis yang dianggap sesuai oleh peneliti (Sarwono, 2006: 117). Pemilihan responden juga memiliki kriteriakriteria tertentu, yakni: a) seorang pengemudi yang berdomisili dan bekerja di Gresik, b) seorang pengemudi mobil angkutan umum selama sama dengan lebih dari lima tahun, c) mendengarkan musik selama sama dengan atau lebih dari 1 jam dalam sehari ketika mengemudi.

Peneliti menggunakan bantuan kuesioner sebagai instrumen dalam proses penggalian data. Jenis data yang dihasilkan adalah data nominal dan ordinal. Temuan data dianalisis menggunakan SPSS menggunakan uji parametrik. Teknik analisis data yang digunakan adalah milik Sarwono, yakni: editing data, memeriksa kelengkapam variabel, koding, cek kesalahan, input, dan tabulasi. Uji yang digunakan adalah Uji Chi-Square. Teknik validitas yang digunakan adalah validitas isi dengan menggunakan Triangulasi. Triangulasi yang dipilih dalam penelitian ini adalah triangulasi sumber. Triangulasi ini "membandingkan data hasil pengamatan dan data hasil wawancara" dan "membandingkan hasil wawancara dengan dokumen yang berkaitan (penelitian terdahulu)" (Moleong, 2011). 


\section{HASIL DAN PEMBAHASAN}

Kota Gresik merupakan salah satu Kota yang berada di Provinsi Jawa Timur. Kota Gresik juga dijuluki sebagai kota industry karena kota Gresik dijadikan sebagai tempat produksi segala jenis barang. Sebagai kota Industry, kota gresik menjadi daya Tarik bagi masyarakat untuk menjadi sumber mata pencarian. Untuk mempermudah aksesbilitas bagi masyarakat, pada tahun 1997 pemerintah Kabupaten Gresik membangun sebuah terminal yang bernama terminal Bus Sidomoro. Terminal tersebut kini berpindah lokasi Jl. Dr. Wahiddin Sudirohusodo, Kecamatan Cerme dan berubah nama menjadi Terminal Bunder.

Terminal bunder menjadi terminal transit beberapa bis antar kota atau provinsi jalur pantai utara (pantura). Terdapat beberapa agent jasa angkutan umum bis antar kota/provinsi yang ada disana seperti Po Haryanto, Gunung Harta Transport, BZRI, Lorena Karina, Nur travel, dan Malino Putra.

Agen transportasi yang pertama yaitu Lorena Karina. Lorena Karina merupakan salah satu perusahaan yang bergerak di bidang jasa transportasi angkutan umum. Mereka memilik beberapa wilayah trayek diantaranya di Pulau Sumantra Jawa, Bali, dan Madura. Terminal Bunder menjadi transit bis Lorena karina dari arah barat (Sumantra, Jakarta dll) menuju Bali dan Madura. Mereka juga membuka agent di Terminal Bunder untuk mempermudah penumpang dari Gresik jika ingin ke kota-kota di Pulau Sumantra, Jawa, Bali dan Madura. Untuk waktu transitnya, mereka transit di Terminal Bunder sore dan malam hari. Setiap bis memiliki fasilitas penunjang untuk menciptakan kenyamanan bagi penumpang salah satunya yaitu tv dan soundsistem.

Agen transportasi kedua yaitu Po Haryanto merupakan salah satu agent transportasi umum berjenis bis yang berdiri sejak tahun 2000 . Mereka memberikan pelayanan transportasi di pulau Jawa dan Madura seperti Jawa Barat, DKI Jakarta, Jawa Tengah, DIY Yogyakarta, dan Jawa Timur. Terminal Bunder menjadi terminal transit bagi penumpang yang dari Pulau Madura dan beberapa Kota di bagian Timur dan Selatan Kota Gresik (Jalur timur dan selatan) dan transit bagi penumpang dari arah barat dan jalur Pantura. Untuk waktu transitnya, mereka biasa tiba di Terminal Bunder Sore dan malam hari. Malam hari memiliki waktu lebih panjang ketika transit karena Terminal Bunder juga digunakan sebagai tempat istirahat. Sebagai salah satu agent trasnportasi antar provinsi, mereka menyediakan fasilitas penunjang untuk memberikan kenyamanan kepada pengemudi dan penumpang. Salah satunya yaitu musik dan tv. Musik digunakan sebagai hiburan bagi pengemudi dan penumpang untuk mengurangi kejenuhan. Pengemudi membutuhkan konsetrasi dan fokus selama perjalanan mengingat jarak yang tempuh cukup jauh.

Agen transportasi Gresik yang ketiga adalah Gunung Harta. Gunung Harta adalah salah satu jasa transportasi darat di bidang tour and travel dengan menggunakan kendaraan jenis bis. Gunung Harta sendiri berasal dari Bali dan menawarkan jasa transportasi untuk wilayah Pulau Bali, Madura dan Jawa. Seperti dengan agent lainnya, mereka transit di Terminal Bunder sore dan malam hari. mereka juga menawarkan beberapa fasilitas penunjang seperti wifi, Tv, musik dan power plug untuk charger dll.

Transportasi lainnya adalah Po Dali Mas merupakan Po bus pariwisata yang berasal dari Bojonegoro, Jawa Timur. Bus Pariwisata ini melayani Transportasi wisata di Indonesia khususnya pulau Jawa, Bali, Lombok dan sebagian Sumantra. Terdapat 3 kelas bis di Po Dali Mas, diantaranya big bus SHD/HHD Dali Mas, Big Bus Dali Mas, dan Medium Bus Dali Mas. Bis yang sudah tidak layak untuk perjalanan wisata, difungsikan sebagai angkutan umum antar kota, seperti yang ada di gambar diatas. Sama halnya bus pariwisata pada umumnya, Po Dali Mas juga menyediakan fasilitas penunjang seperti wifi, tv, musik, dan power plug.

Berdasarkan deskripsi lapangan diatas, maka dapat disimpulkan bahwa bis angkutan umum yang transit di Terminal Bunder Gresik memiliki fasilitas penunjang. Fasilitas-fasilitas tersebut seperti wifi, tv dan musik. Fasilitas tersebut berfungsi sebagai media hiburan bagi penumpang agar terhindar dari kejenuhan dan merasa nyaman selama diperjalanan.

\section{Deskripsi Mendengarkan Musik dan Kenyamanan}

Sasaran responden pada penelitian ini yaitu pengemudi angkutan umum bus antar kota atau antar provinsi yang mendengarkan musik. Seluruh responden menyatakan mendengarkan musik. Masing-masing responden memiliki alasan namun mayoritas mereka menyatakan bahwa mendengarkan musik membantu mereka 
menghilangkan kejenuhan dan memberikan hiburan kepada penumpang.

Sembilan dari sepuluh responden $(90 \%)$ mendengarkan musik dangdut dan hanya 1 responden (1) yang tidak mendengarkan musik dangdut. Berdasarkan keterangan responden, dia tidak selera dengan musik dangdut. Kemudian terdapat 7 responden $(70 \%)$ mendengarkan musik campur sari saat mengemudi dan 3 responden $(30 \%)$ tidak mendengarkan musik campur sari. Berdasarkan keterangan responden, mereka sudah lama mendengarkan musik campur sari. Selain itu, musik campur sari lebih kalem sehingga penumpang bisa nyaman dan tidak terganggu saat tidur. Sedangkan seorang angkutan umum antar provinsi berpendapat bahwa mendengarkan musilk campur sari sudah tidak tren lagi. Penumpang lebih suka dangdut.

Delapan puluh persen saat mengemudi dan sebesar dua puluh persen responden mendengarkan musik saat mengemudi. Menurut keterangan responden, secara pribadi dia tidak suka musik pop. Sehingga kaset musik yang dibawa dan diputar selama mengemudi bukanlah music pop, namun musik dangdut. Sedangkan, responden lain mendengarkan musik pop karena agar tidak bosan. Mendengarkan musik satu jenis saja membuat cepat bosan. Selain itu, penumpang juga ada yang suka dangdut ada juga yang suka pop.

Seratus persen responden tidak mendengarkan musik rock saat mengemudi. Mayoritas responden menjawab bahwa mereka tidak selera dengan music rock. Selain itu, musik rock tidak cocok diputar di kendaraan umum karena terlalu berisik sehingga dapat mengganggu penumpang. Sedangkan untuk musik jazz, 90\% responden tidak mendengarkan musik jazz. Alasan responden tidak mendengarkan musik jazz karena mereka tidak familiar dengan musik tersebut. Selain itu, penumpang mayoritas meminta lagu dangdut untuk diputar. Bagi responden yang sesekali memutar musik jazz, juga pernah memutar musik jazz saat mengemudi. Hal ini karena musiknya enak dan kalem sehingga penumpang nyaman. Meskipun demikian, dia tidak memutarnya setiap hari karena penumpang mayoritas juga lebih suka dangdut.

Berdasarkan pada data-data diatas, dapat disimpulkan bahwa mayoritas responden secara pasti mendengarkan musik saat mengemudi dan mayoritas mereka mendengarkan musik dangdut. Musik dangdut menjadi musik favorit bagi pengemudi sekaligus penumpang sehingga mau tidak mau pengemudi angkutan umum memutar musik dangdut demi kenyamanan penumpang

\section{Variabel Mendengarkan Musik (X)}

Hasil temuan data menunjukkan $50 \%$ setuju dengan pernyataan bahwa mereka mendengarkan music saat bekerja, 30\% sangat setuju dan 20\% responden menyatakan agak setuju atau ragu-ragu. 20\% responden yang menjawab ragu dengan pernyataan di atas dikarenakan mereka tidak setiap hari menyalakan musik saat bekerja. Mereka menyalakan musik tergantung pada situasi dan kondisi. Menyalakan musik saat ramai penumpang dan saat sedang jenuh saja.

Temuan data mengenai penggunaan headset ketika mendengarkan musik adalah sebagai berikut. Lima responden atau $50 \%$ tidak setuju, tiga responden $(30 \%)$ dan dua responden $(20 \%)$ sangat setuju dengan pernyataan mendengarkan musik dengan menggunakan headset. Maka, dapat disimpulkan bahwa mayoritas responden tidak setuju mendengarkan musik dengan menggunakan headset. Mereka berpendapat bahwa mendengarkan musik dengan menggunakan headset dapat berbahaya saat mengemudi. Mereka tidak dapat mendengar tanda klason dari kendaraan lain dan juga tidak mendengar instruksi kernet jika mau menaikkan atau menurunkan penumpang.

Data yang akan dipaparkan berikutnya adalah data persentase tentang kebiasaan responden mendengarkan musik dengan menggunakan speaker aktif. Delapan dari sepuluh responden (80\%) setuju dan dua responden $(20 \%)$ sangat setuju bahwa mereka terbiasa mendengarkan musik dengan speaker aktif. Sehingga dapat disimpulkan bahwa seluruh responden menggunakan speaker aktif saat mendengarkan musik. Alasan responden menggunakan speaker aktif agar penumpang dapat mendengarkan.

Kemudian persentase data kebiasaan mendengarkan musik dengan kencang oleh responden. Sebanyak empat dari sepuluh responden (40\%) agak setuju, empat responden (40\%) tidak setuju dan dua responden (20\%) sangat tidak setuju. Melihat data tersebut dapat disimpulkan bahwa mereka tidak biasa mendengarkan musik secara kencang. Responden beralasan bahwa musik yang kencang membuat penumpang tidak nyaman dan tidak bisa tidur. Selain itu, musik yang terlalu kencang juga mengganggu fokus pengemudi. Jika fokus terganggu, maka resiko terjadi kecelakaan bisa meningkat. 
Persentase data kebiasaan responden menyalakan musik dengan keras agar orang lain juga dengar. Sebanyak lima dari sepuluh responden (50\%) setuju, 3 responden (30\%) agak setuju dan dua responden (20\%) tidak setuju. Berdasarkan pada data tersebut, dapat disimpulkan bahwa setengah dari responden terbiasa menyalakan musik dengan keras agar penumpang dengar hal tersebut dikarenakan musik tersebut diputar dengan volume besar atau keras agar penumpang mendengar dan terhibur. Namun, bagi responden yang ragu - ragu dan tidak biasa memutar musik dengan keras karena mengganggu fokus mengemudi mereka sehingga meningkatkan resiko kecelakaan. Selain itu, mereka juga pernah ditegur oleh penumpang karena suara musik yang keras.

Berdasarkan data-data diatas, maka dapat disimpulkan bahwa semua responden mendengarkan musik saat bekerja. Mereka mendengarkan dengan cara yang beragam yaitu dengan headset dan speaker aktif. Namun, mayoritas dari mereka lebih suka mendengarkan musik dengan menggunakan speaker aktif hal tersebut dikarenakan memutar musik selain untuk mereka sendiri juga untuk didengarkan oleh penumpang.

\section{Variabel Kenyamanan (Y)}

Kenyamanan dan perasaan nyaman adalah penilaian komprenhensif seseorang terhadap lingkungannya. Manusia menilai kondisi lingkungan berdasarkan rangsangan yang masuk ke dalam dirinya melalui keenam indra melalui syaraf dan dicerna oleh otak untuk dinilai. Dalam hal ini yang terlibat tidak hanya masalah fisik biologis namun juga perasaan. Suara, cahaya, bau, suhu, dan lain lain rangsangan ditangkap sekaligus, lalu diolah oleh otak. Kemudian otak akan memberikan penilaian relatif apakah kondisi itu nyaman atau tidak. Ketidaknyamanan di satu faktor dapat ditutupi oleh faktor lain (Satwiko, 2009).

Selain itu, kenyamanan merupakan salah satu komposisi yang dapat menentukan tingkat kepuasan hidup (life satisfaction) seseorang. Hal ini terkait dengan tingkat kesejahteraan pribadi (subjective well-being). Penilaian kenyamanan termasuk dalam indeks yang bersifat nonmaterial, namun memiliki kriteria sebagai pengukur. Adapun kriterianya meliputi terbebas dari panik, suasana hati yang tenang, emosi senang, perasaan aman, dan tidak tertekan (Diener, 2009). Kenyamanan dihubungkan dengan situasi rata-rata yang dihadapi oleh seseorang dalam kehidupan sehari-harinya. Meskipun penilaian berdasarkan perasaan subjektif, faktor yang mempegaruhi kenyamanan berkenaan dengan tingkat kemudahan akses pemenuhan kebutuhan hidup dasar dan lingkungan yang kondusif (dalam hal ini lingkungan kerja supir).

Data persentase kenyamanan responden jika ada penumpang yang menyalakan musik menunjukkan hasil sebagai berikut. Sebanyak delapan responden (80\%) menyatakan setuju dengan pernyataan jika musik membuat penumpangna nyaman. Kemudian dua responden yang ragu-ragu dengan hal ini. Responden merasa tidak masalah dan tidak terganggu jika ada penumpang yang menyalakan musik. Sehingga dapat disimpulkan bahwa responden tidak mempermasalahkan hal tersebut.

Kemudian data berikutnya adalah persentase pengaruh musik terhadap fokus pengemudi. Ditemukan bahwa dari sepuluh responden sebanyak enam responden $(60 \%)$ setuju bahwa musik membantu mereka lebih fokus saat mengemudi. Sisanya sebanyak tiga responden $(30 \%)$ menjawab sangat setuju dan satu responden (10\%) menjawab agak setuju atau ragu-ragu. Berdasarkan data tersebut, maka dapat disimpulkan bahwa mayoritas responden menjadi lebih fokus mengemudi jika mendengarkan musik.

Selanjutnya adalah data persentase musik membantu meredakan emosi responden saat mengemudi. Berdasarkan data tersebut, dari sepuluh responden ditemukan bahwa sebanyak lima responden (50\%) menjawab setuju bahwa musik membantuk mereka untuk meredakan emosi. Empat responden (40\%) menjawab agak setuju atau ragu-ragu. Selain itu, hanya satu responden (10\%) menjawab tidak setuju. Dapat disimpulkan bahwa sebagian besar responden membenarkan atau setuju bahwa musik dapat membantu mereka meredakan emosi. Namun sebagian kecil masih ragu atau tidak setuju karena berdasarkan pengalaman mereka pernah emosi mereka semakin meningkat karena musik yang terlalu kencang disaat cuaca panas.

Persentase musik membantu responden meredakan stress saat mengemudi mendapatkan hasil sebagai berikut. Berdasarkan pada data tersebut, ditemukan bahwa dari sepuluh responden sebanyak empat responden (40\%) menjawab setuju bahwa musik membantu 
mengurangi stress responden saat mengemudi. Empat responden $(40 \%)$ agak setuju atau raguragu. Kemudian dua responden $(20 \%)$ sisanya sangat setuju. Oleh karena itu, dapat disimpulkan bahwa mayoritas responden membenarkan bahwa mendengarkan musik saat bekerja atau mengemudi dapat membantu mereka mengurangi stress.

Ada juga persentase pengaruh musik pada kenyaman penumpang di dalam angkutan umum. Temuan data di lapangan menemukan bahwa sebanyak lima dari responden menjawab setuju bahwa penumpang nyaman dan terhibur jika ada musik saat diangkutan umum. Selain itu, empat responden (40\%) menjawab sangat setuju dan hanya satu responden (10\%) yang agak setuju. Menurut keterangan responden, penumpang sendiri yang meminta untuk dinyalakan atau diputarkan musik. Dengan demikian, dapat disimpulkan bahwa mayoritas penumpang tidak masalah jika responden menyalakan musik.

\section{Tingkat Pengaruh Mendengarkan Musik Bagi Kenyamanan Pengemudi Mobil Angkutan Umum}

Hasil jawaban dari pertanyaan-pertanyaan pada variabel mendengarkan musik $(X)$ dan kenyamanan (Y) telah ditemukan. Tahap selanjutnya menentukan tingkat hubungan atau pengaruh dua variabel tersebut dengan menggunakan tabel distribusi frekuensi dan rating scale. Distribusi frekuensi merupakan suatu susunan data yang dimulai dari yang terkecil hingga terbesar. Kemudian dibagi dalam beberapa kelas. Atau disusun berdasarkan pada kelompok-kelompok atau kategori tertentu dengan masing-masing frekuensi. Sehingga dapat memberikan gambaran sederhana dari suatu kumpulan. Sedangkan rating scale merupakan salah satu skala pengukuran yang digunakan sebagai acuan untuk menentukan panjang pendeknya suatu interval. Rating scale juga dapat digunakan sebagai alat ukur kuat tidaknya hubungan antar variabel (Sugiyono, 2009).

Tabel 1 Distribusi Frekuensi per item pertanyaan

\begin{tabular}{|c|c|c|c|c|c|c|c|c|c|c|c|}
\hline $\begin{array}{c}\text { KODE } \\
\text { PERTANYAAN }\end{array}$ & $\begin{array}{c}\mathrm{X} \\
1\end{array}$ & $\begin{array}{c}\mathrm{X} \\
2\end{array}$ & $\begin{array}{c}\mathrm{X} \\
3\end{array}$ & $\begin{array}{c}\mathrm{X} \\
4\end{array}$ & $\begin{array}{c}\mathrm{X} \\
5\end{array}$ & $\begin{array}{c}\mathrm{Y} \\
1\end{array}$ & $\begin{array}{c}\mathrm{Y} \\
2\end{array}$ & $\begin{array}{c}\mathrm{Y} \\
\mathbf{4}\end{array}$ & $\begin{array}{c}\mathrm{Y} \\
\mathbf{5}\end{array}$ & SKOR \\
\hline $\begin{array}{c}\text { SANGAT } \\
\text { TIDAK KUAT }\end{array}$ & 0 & 3 & 0 & 2 & 0 & 0 & 0 & 0 & 0 & 0 & \\
\hline TIDAK KUAT & 0 & 5 & 0 & 4 & 2 & 0 & 0 & 1 & 0 & 0 & \\
\hline CUKUP KUAT & 2 & 2 & 0 & 4 & 3 & 2 & 1 & 4 & 4 & 1 & \\
\hline KUAT & 5 & 0 & 8 & 0 & 5 & 8 & 6 & 5 & 4 & 5 & \\
\hline SANGAT KUAT & 3 & 0 & 2 & 0 & 0 & 0 & 3 & 0 & 2 & 4 & \\
\hline SKOR & $\mathbf{4}$ & $\mathbf{1}$ & $\mathbf{4}$ & $\mathbf{2}$ & $\mathbf{3}$ & $\mathbf{3}$ & $\mathbf{4}$ & $\mathbf{3}$ & $\mathbf{3}$ & $\mathbf{4}$ & \multirow{2}{*}{$\mathbf{3 5 6}$} \\
\hline
\end{tabular}

Tabel diatas merupakan distribusi frekuensi di setiap pertanyaan dan skor dari jawaban yang dipilih responden. Untuk jawaban sangat tidak kuat mendapat skor 1, tidak kuat skor 2, cukup kuat skor 3, kuat skor 4 dan sangat kuat skor 5. Dengan skor tersebut, ditemukan skor per pertanyaan dan skor total. Skor tersebut digunakan untuk menentukan rating scale. Rating scale berfungsi untuk melihat hasil akhir korelasi variabel mendengarkan musik $(\mathrm{X})$ dan variabel kenyamanan $(\mathrm{Y})$.

$$
\begin{aligned}
& \text { Nilai Indeks minimum }= \\
& =\text { skor minimum } \mathrm{x} \text { jumlah pertanyaan } \mathrm{x} \text { jumlah } \\
& \text { responden } \\
& =1 \times 10 \times 10 \\
& =100
\end{aligned}
$$

$$
\begin{aligned}
& \text { Nilai indeks maksimum }= \\
& =\text { skor maksimum } \times \text { jumlah pertanyaan } \times \text { jumlah } \\
& \text { responden } \\
& =5 \times 10 \times 10 \\
& =500
\end{aligned}
$$
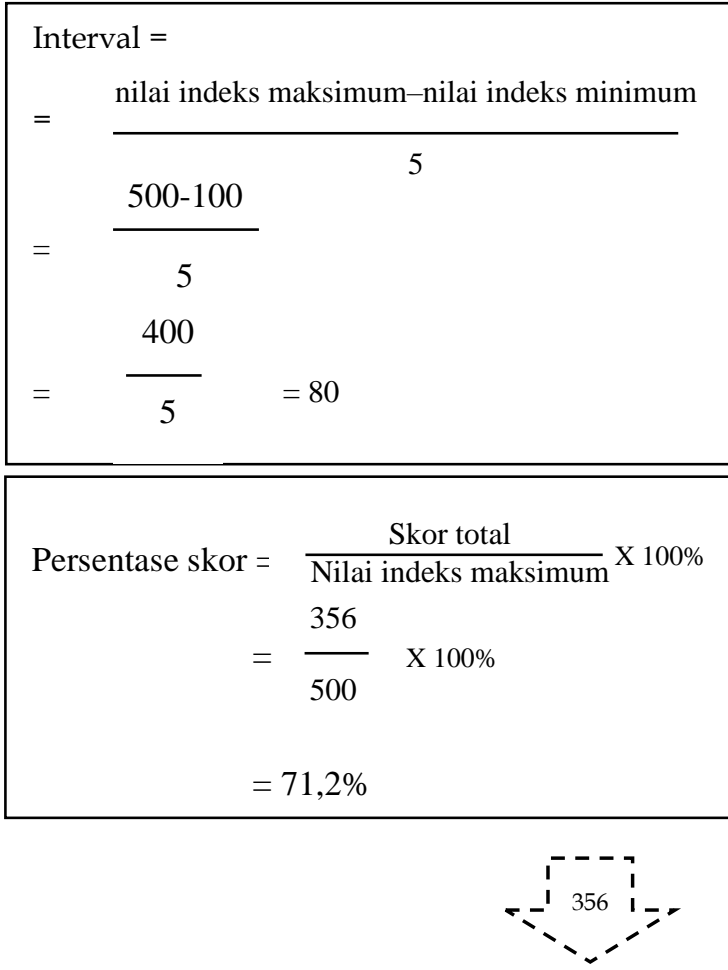

Skor Minimum Skor

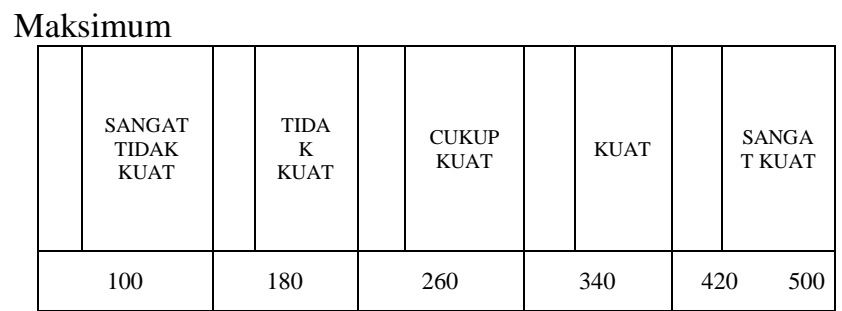


Data diatas menunjukkan korelasi antara variabel mendengarkan musik $(\mathrm{X})$ dan variabel kenyamanan mengemudi $(\mathrm{Y})$. melalui data diatas, terlihat bahwa skor total jawaban responden adalah 356 atau sebesar 71,2\%. Melalui metode rating scale, maka ditemukan bahwa skor tersebut berada pada antara 340-420 atau kategori KUAT dan siginfikan. Dengan demikian, maka dapat disimpulkan bahwa mendengarkan musik memiliki pengaruh yang kuat atau signifikan terhadap kenyamanan pengemudi angkutan umum di Terminal Bunder Gresik.

\section{Mendengarkan Musik dan Kenyamanan Pengemudi Angkutan Umum}

Musik merupakan sebuah karya seni bunyi (suara) yang diciptakan oleh manusia. Ini merupakan bentuk pengaktualisasian pikiran dan perasaan penciptanya melalui komposisi atau karya musik yang dihasilkan. Musik merupakan seni pengungkapan gagasan melalui bunyi. Unsur dasarnya berupa melodi, irama, dan harmoni, dengan unsur pendukung berupa bentuk gagasan, sifat, dan warna bunyi. Melalui unsur-unsur dasar tersebut, lahirlah berbagai jenis genre musik seperti musik pop, jazz, funk, rock, dangdut dan lain sebagainya. Genre-genre tersebut.

Genre musik lahir sebagai bentuk dari kompleksitas dari masyarakat, pemasaran, sejarah, dan faktor budaya (Tzanetakis \& Cook, 2002). Terdapat beberapa jenis genre yang popular di Indonesia seperti dangdut, pop, dan funk. Namun, dari ke tiga genre tersebut genre dangdut yang paling popular di kalangan pengemudi sopir mobil angkutan umum di terminal bunder Kota Gresik. dari 10 sopir yang diwawancarai, 9 diantaranya suka mendengarkan atau memutar musik dangdut saat mengemudi daripada genre musik yang lain. Musik dangdut dinilai lebih mudah diterima oleh penumpang sebagai hiburan saat di dalam kendaraan. Hal tersebut dikarenakan musik dangdut memiliki irama syair melayu sehingga nyaman didengar.

Selain itu, musik dangdut juga sering digunakan sebagai huburan rakyat menengah ke bawah sebagai media hiburan, dakwah dan kampanye (Fathin dan Johny, 2012). Pengemudi memiliki beragam alasan dan pertimbangan dalam memutar musik dan memilih jenis musik. Mereka memutar musik digunakan untuk membantu mereka meredakan emosi, menghibur penumpang, dan menghilangkan kejenuhan. Mereka merasa nyaman dengan adanya musik saat berkendara.
Menurut Diener (2009), kenyamanan mereka dalam mendengarkan musik dapat dilihat dari dampak yang ditimbulkan. Seperti hilangnya rasa cemas, panik, suasana hati tenang, emosi senang, perasaan aman dan tidak tertekan. Meskipun hal tersebut merupakan penilaian subyektif, faktor yang mempengaruhi kenyamanan berkenaan dengan tingkat kemudahan akses pemenuhan kebutuhan hidup dan lingkungan kerja sopir. Oleh karena itu, dengan mendengarkan musik merupakan faktor pemberi kenyamanan sehingga membantu sopir untuk memperlancar pekerjaan mereka.

Kenyamanan dalam mendengarkan muik termasuk dalam proses apresiasi musik. Apresiasi musik adalah suatu kegiatan penghayatan dan penghargaan terhadap suatu karya seni musik. Terhadap beberapa tahapan dalam kegiatan apresiasi musik yaitu mengamati, menghayati dan mengevaluasi. Dari ketiga tahapan tersebut, sopir mobil angkutan umum di terminal bunder Gresik masuk dalam tahapan mengamati dan menghayati. Dalam tahap mengamati, mereka hanyut dalam proses mendengarkan lagu-lagu dangdut yang diputar dalam angkutan umum yang mereka kemudikan. Mereka tidak mempermasalahkan jika ada penumpang yang memutar musik di dalam angkutan. Selain itu, 90\% dari mereka dipastikan mendengarkan musik setiap mereka bekerja.

Terdapat dua faktor yang mempengaruhi seseorang dalam berapresiasi pada musik. Yaitu faktor internal dan faktor eksternal. Kedua faktor tersebut bisa bersifat mendukung atau menghambat. Faktor internal adalah faktor yang berasal dari diri setiap individu seperti minat dan motivasi. Minat seseorang berhubungan erat dengan bidang atau pekerjaan yang dilakukan karena intensitas dalam mendengarkan musik menentukan apresiasi yang diberikan. Sedangkan motivasi yaitu kondisi yang sangat dibutuhkan seseorang.

Musik digunakan sebagai motivasi dalam menjalani kehidupan sehari-hari. Setiap sopir angkutan umum di Terminal Bunder memiliki minat dalam mendengarkan musik. Mereka selalu mendengarkan musik setiap hari. Motivasi nya adalah musik dapat membantu mereka untuk mendapatkan kenyamanan dalam bekerja, menjadi lebih fokus, tenang dan tidak emosial sehingga meningkatkan semangat kerja. Sedangkan faktor eksternal adalah faktor yang datang dari luar individu. Sebagaimana diketahui 
bahwa proses kehidupan manusia adalah bersama keluarga dan bersama lingkungan masyarakat.

Setiap situasi, baik di keluarga maupun di masyarakat dapat mempengaruhi proses dalam perkembangan apresiasi seseorang dalam memandang suatu hasil karya seni termasuk sopir angkutan umum di Terminal Bunder. Mereka mendengarkan musik juga dipengaruhi oleh kebutuhan penumpang untuk mendapatkan hiburan. Perjalanan yang jauh bisa menimbulkan kebosanan dan kejenuhan sehingga dibutuhkan hiburan berbentuk musik untuk menghilangkan situasi tersebut. Sopir juga tidak keberatan jika penumpang meminta diputarkan musik atau mereka memutar musik sendiri. Hal tersebut dapat memberikan kesan baik dan nyaman atas pelayanan yang diberikan.

\section{PENUTUP}

Musik merupakan salah satu solusi alternatif bagi pengemudi angkutan umum untuk menghadapi stress. Berdasarkan pada riset yang dilakukan di terminal Bunder Gresik, dari 10 responden sopir angkutan umum bis kota dan provinsi, mereka semua menyatakan mendengarkan musik setiap mereka mengemudi. Mereka mayoritas mendengarkan musik dangdut ( $90 \%$ ) dan hanya $1 \%$ yang mendengarkan selain dangdut. dalam mendengarkan musik, $80 \%$ responden mendengarkan musik dengan menggunakan speaker aktif dan 50\% responden menolak menggunakan headset. Alasan mereka menggunakan speaker aktif agar orang lain juga ikut mendengar. Selain itu, mayoritas responden juga menjawab bahwa mereka bisa lebih fokus saat mengemudi, membantu meredakan emosi, dan membantu meredakan strees. Dan juga musik yang diputar oleh pengemudi membuat penumpang nyaman dan terhibur. Sehingga dapat disimpulkan bahwa kedua variabel tersebut memiliki hubungan yang KUAT atau signifikan. hal tersebut dapat dilihat pada skor total yang dihasilkan oleh responden yaitu 356 atau 71,2\% melalui metode rating scale.

Berdasarkan pada temuan-temuan yang telah diteliti, peneliti memberikan saran yaitu pemerintah untuk lebih memperhatikan permasalahan kemacetan karena permasalahan tersebut dapat mendorong meningkatnya stress dan emosi pengendara sehingga dapat berpeluang terjadi kecelakaan. Selain itu, saran untuk pengemudi bahwa yang mendengarkan musik diharapkan tidak dengan volume terlalu keras. Hal itu justru dapat mengganggu konsentrasi dan tidak bisa fokus mendengar rambu-rambu atau klakson dari pengendara lain.

\section{DAFTAR PUSTAKA}

Bonoe, P. (2003). Kamus Musik. Yogyakarta: Best Publisher

Depdikbud, (2001). Kamus Besar Bahasa Indonesia

Diener, Ed. (2009). Social Indicators Research Series: Assesing Subjective Well-Being London: Springer.

Djohan, (2005). Psikologi Musik. Yogyakarta: Penerbit Buku Baik

google.com/amp/s/amp.suara.com/health/2016/0 2/02/195500/penyakit-ini-rentan-dialamisupir-angkutan diakses pada tanggal 10 November 2019 pukul 21.00 WIB

google.com/amp/s/amp.tirto.id/bagaimanamusik-mempengaruhi-cara-pandang-kita

https://daerah.sindonews.com/read/782556/21/so pir-angkot-mudah-kena-stress1379039997

https://www.kompasiana.com/amp/edwinjpohan/ musik-klasik-meningkatkan-kecerdasan550b4a22a333119d712e3e9aMarzuki, Latifah K. (1995). Istilah-istilah Musik. Jakarta: Djambatan

Moleong, L.J. 2011. Metode Penelitian Kualitatif. Bandung: PT Rosdakarya

Prier, Karl-Edmund, SJ. (2014). Kamus Musik. Yogyakarta: Pusat Liturgi Musik

Sarwono, J. (2006). Metode Penelitian Kuantitatif dan Kualitatif. Yogyakarta: Graha Ilmu.

Satwiko. (2009). Fisika Bangunan. Yogyakarta: Andi

Sugiyono. 2009. Metode Penelitian Kuantitatif Kualitatif dan $R \& D$. Bandung : Alfabeta

Syafiq, M. (2003). Ensiklopedia Musik Klasik. Yogyakarta: Adicita Karya Nusa

Testamentyas, H., M.B.G. Saputra, dan I.B.W. Aji. 2018. Pengaruh Psikologis Mendengarkan Musik Bagi Pengendara Mobil di Surabaya. Surabaya: Universitas Negeri Surabaya. 